\title{
PENERAPAN BAHAN AJAR AUDIO UNTUK ANAK TUNANETRA TINGKAT SMP DI INDONESIA
}

\author{
Agnes Praptaningrum \\ Teknologi Pendidikan, Fakultas Ilmu Pendidikan, Universitas Negeri Malang \\ agnes.praptaningrum.1801216@students.um.ac.id
}

\begin{abstract}
Abstrak: Tunanetra adalah orang yang tidak dapat melihat (buta total) dan dapat melihat hanya melihat cahaya (kurang awas). Keterbatasan dalam melihat dapat dibantu dengan media audio yang menekankan pada pedengaran. Media ini cocok karena anak tunanetra memiliki pendengaran yang sangat tajam apabila dilatih terus menerus. Pendengaran yang sangat tajam ini dapat dimanfaat untuk pembelajaran dengan menggunkan media audio. Siswa SMP tunanetra memiliki kosentrasi yang lebih tinggi daripada anak SD jadi media ini akan cocok bila dijadikan media pada siswa SMP. Media ini akan mempermudah pembelajaran pada siswa SMP tunanetra dalam melakukan pembelajaran dan menerima materi.Audio Tujuan artikel adalah mengetahui kelayakan dan efektivitas pada penerapan media audio sebagai bahan ajar siswa tunanetra tingkat SMP. Penelitian ini menggunakan sempeling dari artikel-artikel sebelumnya yang terkait dengan judul penelitian ini. Dari hasil kegiatan telaah artikel-artikel sebelumnya menyebutkan bahwa dengan menggunakan media audio siswa tunanetra lebih termotivasi dan dapat mudah memahami pembelajaran, serta dapat belajar dan membayangkan suara yang didengar dengan audio sehingga siswa tunanetra dapat lebih memahami materi yang disampaikan.
\end{abstract}

Kata kunci: Media Auido, Siswa Tunanetra, Bahan ajar

\begin{abstract}
Blind people are people who can not see (totally blind) and can see only see the light (less alert). Limitations in seeing can be helped by audio media that emphasizes hearing. This media is suitable because blind children have very sharp hearing when practiced continuously. This very sharp hearing can be used for learning by using audio media. Blind Junior High School students have a higher concentration than elementary school children so this media will be suitable if used as a medium for junior high school students. This media will facilitate learning in junior high school students who are blind in learning and receiving material. Audio The purpose of the article is to determine the feasibility and effectiveness of the application of audio media as teaching material for blind students at the junior high level. This study uses a series of previous articles related to the title of this research. From the results of the study of previous articles quoting that by using audio media, blind students are more motivated and can easily learn, can also learn and understand sounds heard with audio so that blind students can better understand the material presented.
\end{abstract}

Keywords:Audio Media, Blind Students, Teaching Materials 


\section{PENDAHULUAN}

Pada dasarnya semua anak harus mendapatkan pendidikan yang sama anak normal maupun anak bekebutuhan khusus. Siswa tunanetra adalah individu yang mengalami gangguan penglihatan, sehingga mengalami keterbatasan dan kesulitan melakukan kegiatan sehari-hari termasuk kegiatan belajar (Badiah, 2016). Dalam kehidupan sehari-hari siswa tunanetra untuk menyerap informasi atau pesan, dengan menggunakan indera yang masih berfungsi dengan baik, diantaranya indera peraba, dan indera pedengaran. Pendengaran yang diperoleh siswa tunanetra tidak didapat secara alami, namun harus diajarkan secara sistematis.

Keterampilan mendengar mempunyai peran penting dalam proses pembelajaran. Berbeda dengan siswa awas, hampir $80 \%$ informasi diperoleh dari indera visual, namun bagi siswa tunanetra, indera pendengarnya (auditory) menjadi salah satu sumber penting untuk memperoleh informasi sebagai kompensasi gangguan penglihatannya dan tunanetra menggunakan pendengaran sebagai media dua kali lipat dibandingkan dengan membaca.

Pendidikan merupakan salah satu bentuk pelayanan dalam meningkatkan kualitas sumber daya manusia sesuai perkembangan dan kemajuan zaman. Undang-Undang, 2003 tentang Sistem Pendidikan Nasional pada bab IV pasal 5 ayat 1 menyatakan bahwa setiap warga negara mempunyai hak yang sama untuk memperoleh pendidikan yang bermutu, sedangkan ayat 2 menyatakan bahwa warga negara yang mempunyai kelainan fisik, emosinal, mental, intelektual, dan sosial berhak memperoleh pendidikan khusus, sehingga pendidikan tidak hanya untuk anak normal saja tetapi juga untuk anak berkebutuhan khusus.

Bahwa bahan ajar merupakan seperangkat informasi yang harus diserap peserta didik melalui pembelajaran yang menyenangkan. Secara umum bahan ajar dapat dibedakan ke dalam bahan ajar cetak dan noncetak. Bahan ajar cetak dapat berupa, handout, buku, modul, brosur, dan lembar kerja siswa. Sedangkan 
bahan ajar noncetak meliputi, bahan ajar audio seperti, kaset, radio, piringan hitam, dan compact disc audio (Priambodo, 2019). Bahan ajar audio visual seperti, CAI (Computer Assisted Instruction), dan bahan ajar berbasis web (web based learning materials) (Budiarso, 2016).

(Sulfemi,

menyampaikan media audio visual adalah media yang mempunyai unsur suara dan unsur gambar. Media ini mempunyai kemampuan yanglebih baik, karena meliputi kedua jenis media auditif atau mendengar dan visual atau melihat. Media audio visual adalah alat bantu audio visual yang berupa alat yang dipergunakan dalam pembelajaran untuk membantu tulisan dan kata yang diucapkan dalam mentransfer pengetahuan, sikap, danide. Media audio visual merupakan media perantara atau penggunaan materi dan penyerapannya melalui pandangan dan pendengaran sehingga membangun kondisi yang dapat membuat peserta didik mampu memperoleh pengetahuan, keterampilan, atau sikap.
Beberapa penelitian terdahulu telah mengembangkan beberapa cara untuk memudahkan siswa tunanetra dalam belajar seperti (Widyastuti, 2016) yang mengembangkan buku pengayaan apresiasi sastra berhuruf braille Indonesia dengan media reglet, (Satrio, 2016) yang mengembangkan modul kimia berbasis EPUB, (Masruro \& Winarti, 2012)mengembangkan modul IPA Fisika materi suhu,(Tirta et al., 2013) mengembangkan alat peraga matematika berbasis audio, (Khamdun, 2015) mengembangkan Media Pembelajaran IPA Berbasis Alam, (Fatihatul \& Budiawanti, 2013) membuat media pembelajaran berupa kit percobaan penentuan percepatan gravitasi dengan neraca pegas braille untuk siswa tunanetra kelas VIII . Beberapa perangkat lunak pendidikan interaktif untuk anak-anak tunanetra. Contohnya pada penelitian Laksono, 2016 memperkenalkan Musik braille untuk mengajar musik kepada anak-anak tunanetra. Musibraille sekarang menggabungkan fungsi yang ditujukan untuk mengajar anakanak,sehingga memungkinkan banyak eksperimen dan pendekatan pendidikan 
yang menarik dapat dilakukan. Tujuan kami adalah untuk menggabungkan fasilitas dengan tujuan pendidikan . Aplikasi pengetikan berbasis braille untukperangkat layar sentuh yang disebut TypeInBraille . TypeInBraille membutuhkan penggunaan setidaknya tiga jari. Akibatnya, itu benartidak mungkin menggunakan teknik ini memegang perangkat di satu tangan dan mengetik dengan ibu jari. Apalagi yang bebas mata aplikasi entri teks untuk perangkat seluler yang disebut BrailleTouch yang diperkenalkan oleh Frey tahun 2011. Sistem-sistem itu digunakan layar sentuh dan disampaikan dalam bahasa Inggris. Dalam penelitian Sari et al., 2019 bahwa pendekatan gamification untuk aplikasi media pembelajaran dapat membantu anak-anak tunanetra tidak hanya belajar mengetik tetapi juga dapat mengulangi materi pembelajaran yang disesuaikandari kurikulum pendidikan di Indonesia. Sebelumnya ada aplikasi media pembelajaran dengan gamification pendekatan, yaitu Taxology . Perbedaannya adalah aplikasi media pembelajaran ini menggunakan platform Windows.
Berdasarkan data google tren audio lebih banyak dicari dibandingkan dengan huruf braille seperti yang ditunjukkan pada gambar.1.

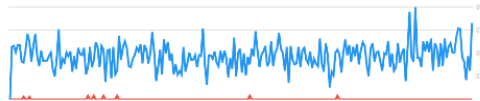

Gambar 1. Grafik audio dan huruf braille

Gambar.1. merupakan grafik yang menujukkan garis biru adalah audio dan merah huruf braille. Pada gambar menujukkan lebih besar garis biru menunjukkan banyaknya pencarian pada audio daripada huruf braille. Ruang lingkup telaah merupakan tujuan/fokus/konsentrasi yang akan dijalankan sehingga tidak melenceng dari area/ruang lingkup yang nantinya akan dikerjakan.

Ruang lingkup dari artikel telaah ini yaitu menggunakan pembelajaran audio sebagai media pembelajaran bagi kalangan siswa SMP tunanetra agar pembelajaran bagi siswa tunanentra dapat dipelajari dengan mendengarkan serta dapat melatih motorik anak tunanetra agar dapat membayangkan sebuah benda dengan detail sesuai dengan audio yang 
diputar. Maka dari itu ruang lingkup pada artikel ini tertuju pada pembelajaran audio sebagai media pembelajaran pada siswa smp tuananetra.

Hasil penelitian diperoleh dari pengolahan data dari artikel-artikel terkait. Penelitian ini bertujuan (1) mengetahui pengaruh pembelajaran praktik berbantuan media audio terhadap kemampuan (2) mengetahui dampak media audio untuk anak tunanetra.

\section{HASIL}

\section{Tunanetra}

\subsection{Pengertian Tunanetra}

Pendidikan merupakan salah satu bentuk pelayanan dalam meningkatkan kualitas sumber daya manusia sesuai perkembangan dan kemajuan zaman. Undang-Undang, 2003 tentang Sistem Pendidikan Nasional pada bab IV pasal 5 ayat 1 menyatakan bahwa setiap warga negara mempunyai hak yang sama untuk memperoleh pendidikan yang bermutu, sedangkan ayat 2 menyatakan bahwa warga negara yang mempunyai kelainan fisik, emosinal, mental, intelektual, dan sosial berhak memperoleh pendidikan khusus, sehingga pendidikan tidak hanya untuk anak normal saja tetapi juga untuk anak berkebutuhan khusus.

Tunanetra pada hakikatnya adalah kondisi dari mata atau daria penglihatan yang karena sesuatu hal tidak berfungsi sebagaimana mestinya, sehingga mengalami keterbatasan dan atau ketidak mampuan melihat. Dalam hal ini, tuna berarti luka, rusak, kurang atau tiada memiliki. Netra berarti mata atau indra penglihatan (Indrastuti, 2015).

Secara harafiah tunanetra berasal dari dua kata, yaitu: Tuna (tuno:Jawa) yang berarti rugi yang kemudian diidentikan dengan rusak, hilang, terhambat, terganggu tidak memiliki dan netra (netro:Jawa) yang berarti mata (Indrastuti, 2015). Namun demikian kata tunanetra adalah satu kesatuan yang tidak terpisahkan yang berarti adanya kerugian yang disebabkan oleh kerusakan atau terganggunya organ mata, baik anatomis maupun fisiologis, Oleh karena itu tunanetra dibagi menjadi dua. Pertama buta total (total blind), 
jika sama sekali tidak mampu menerima rangsang cahaya dari luar visusnya. Kedua low vision, bila ketajaman penglihatannya kurang dari 6/21 (Widyastuti, 2016).

\subsection{Karakteristik Anak Tunanetra}

Kemampuan yang berbeda pada anak normal dengan anak yang memiliki kebutuhan khusus seperti tunanetra yang memiliki kemampuan berhitung yang sama seperti anak normal dan dapat menerima informasi seperti anak normal tetapi memiliki kesulitan dalam pemahaman yang berhubungan dengan penglihatan. Kesulitan yang dimiliki anak tunanetra dalam mengguasai ketrampilan sosial dapat dilihat saat anak tunetra berhubungan dengan orang luar yang begitu banyak mereka akan kaku dan ucapan akan kurang sesuai karena tidak dapat melihat situasi disekitarnya. Anak tunanetra akan lebih menunjukkan kepekaan dengan beda sekitar dengan cara meraba dan menajamkan indera pendengaran agar dapat membaca situasi disekitarnya (Ulya, 2014).

\section{Media Pembelajaran}

2.1 Pengertian Media Pembelajaran

Mulyono, n.d. mengungkapkan bahwa bahan ajar merupakan seperangkat informasi yang harus diserap peserta didik melalui pembelajaran yang menyenangkan. Secara umum bahan ajar dapat dibedakan ke dalam bahan ajar cetak dan noncetak. Bahan ajar cetak dapat berupa, handout, buku, modul, brosur, dan lembar kerja siswa. Sedangkan bahan ajar noncetak meliputi, bahan ajar audio seperti, kaset, radio, piringan hitam, dan compact disc audio. Bahan ajar audio visual seperti, CAI (Computer Assisted Instruction), dan bahan ajar berbasis web (web based learning materials) (Wijaya, 2016).

Menurut (Camalia, 2016) menyatakan bahwa media pembelajaran adalah berbagai macam struktur untuk pesan atau substansi latihan yang tepat, pemberian energi dan perangkat memberi instruktur untuk mendukung siswa. Mengingat definisi di atas cenderung tertutup itulah media pembelajaran yang dapat dimanfaatkan untuk menyampaikan materi pembelajaran kepada siswa agar 
mereka bisa mencapai tujuan dari proses pendidikan dan pembelajaran.

\subsection{Kegunaan Media \\ Pembelajaran}

Seperti yang ditunjukkan oleh Sudjana (2010: 23) estimasi kesungguhan dari media pembelajaran, khususnya: (1) Pemanfaatan media pembelajaran pada dasarnya bukan kapasitas apalagi, lebih dari itu sebagai alat untuk menjalankannya pembelajaran yang semakin menarik; (2) jelaskan pesannya agar tidak berlebihan kata kerja; (3) mengalahkan pembatasan ruang, waktu, vitalitas, dan kekuatan indera; (4) menggairahkan energi pembelajaran;

memungkinkan anak-anak untuk beradaptasi secara bebas sesuai kebutuhan dengan karunia dan kapasitas visual, terkait suara, dan sensasi; dan (6) memberikan pengamatan tingkat harga dorongan yang serupa.

\section{Media Audio}

(Haryoko, menyampaikan media audio visual adalah media yang mempunyai unsur suara dan unsur gambar. Media audio tersebut dapat meningkatkan motivasi dan hasil belajar siswa dikarenakan lagu yang bermuatan materi pelajaran dapat membuat materi dapat lebih mudah dipahami dan disimpan dalam memori jangka panjang (Hidayati \& Pribadi, 2014). Media ini diharapkan akan mengoptimalkan indera yang masih berfungsi yaitu indera pendengaran tetapi tidak mengesampingkan peran guru sebagai pembimbing dalam proses pembelajaran karena ketika seorang anak mengalami ketunanetraan, maka pengalaman harus diperoleh dengan mempergunakan indera yang masih berfungsi, khususnya perabaan dan pendengaran.

Keunggulan modul audio dalam kegiatan pembelajaran pada umumnya untuk melatih keterampilan yang berhubungan dengan aspek-aspek keterampilan mendengarkan (Badiah, 2016). Media ini mengandung pesan dalam bentuk auditif (hanya dapat didengar) sehingga dapat merangsang pikiran, perasaan, perhatian, dan membantu dalam memperoleh pengetahuan, keterampilan, atau sikap. Pembelajaran dengan modul audio interaktif sebagai media bagi siswa 
tunanetra untuk melakukan interaksi dengan pembelajaran. Menurut Dariyati et al., 2015 media audio adalah media untuk menyampaikan pesan yang akan disampaikan dalam bentuk lambang- lambang auditif, baik verbal maupun non verbal.

\section{Jenis Media Audio}

Investigasi yang dipimpin oleh Kephart dan Schwartz (1974, dalam MA SPLASH 2014) menunjukkan bahwa siswa yang mengalami debilitasi visual ekstrem akan secara umum menambah kemampuan hubungan verbal, dan dapat melebihi harapan, misalnya, siswa pengganti (ada berbagai tes yang dikelola negara). Kemudian lagi, kapasitas mereka untuk persiapan data sering kali berakhir dalam pengertian yang terbagi atau kurang, bahkan dalam ide langsung. Investigasi tersebut menunjukkan bahwa debilitasi visual seseorang akan dapat mempengaruhi pencapaian ilmiah individu. Mendengar adalah fakultas mereka yang dapat dimanfaatkan untuk membuat kemajuan. Selanjutnya, perluasan dalam pemanfaatan media pembelajaran yang terkait dengan suara dan materi dapat membantu siswa dalam latihan skolastik. Media pembelajaran suara adalah pesan pembelajaran yang diperkenalkan pada premis suara yang direncanakan untuk menyegarkan renungan, sentimen, pertimbangan, dan kapasitas siswa. Untuk mencapai tujuan ini, pengantar pesan dibuat dengan memikirkan materi yang benar dan pengantar yang menarik sehingga siswa tidak merasa lelah.

Menurut (Indrastuti, 2015) Dari beberapa penelitian sebelumnya, peneliti mencoba menyesuaikan inovasi pembelajaran untuk anak-anak tunanetra dengan menggunakan telepon seluler yang belum pernah selesai. Melalui upaya bersama antara QR Code, sound, dan middle, penyesuaian media pembelajaran diandalkan untuk menghubungkan kurangnya media pembelajaran auditif pada Sains dan meningkatkan kemampuan para tunanetra yang sedang bekerja, untuk lebih spesifik fakultas. pendengaran dan kontak. Dalam pemanfaatan bunyi tengah dalam merenungkan struktur tubuh dan lainnya, adalah normal bahwa siswa tunanetra menjadi 
semakin mandiri dan siap untuk membangun kapasitas mereka dan membuatnya lebih mudah bagi mereka untuk memahami ide-ide dalam bahan alami yang diidentifikasi dengan pemanfaatan perantara.

Media audio SPLASH yang dipergunakan untuk mata pelajaran IPA khususnya wujud benda kepada 4 siswa yang memiliki kekurangan yaitu buta total. Siswa-siswa yang buta total ini memiliki kekurangan yang sama tetapi memiliki karakteristik yang berbeda. Karakteristik yang berbeda-beda ini dapat mempengaruhi hasil media audio yang dipakai. Hasil yang didapat juga berbeda-beda tergantung daya tangkap dari setiap siswa tersebut. Media audio membuat hasil belajar meningkat meskipun siswa memiliki karakteristik yang berbeda-beda (Delani, 2017).

Penyesuaian peralatan belajar diidentifikasi dengan aturan ketersediaan anak-anak tunanetra, diantaranya : (1) Memfasilitasi, yaitu, semua orang dapat tiba di semua tempat atau struktur yang teratur dalam suatu situasi. (2) Gunakan, yaitu, setiap orang harus memiliki opsi untuk bergantung pada semua tempat atau struktur yang merupakan tempat terbuka dalam domain. (3) Keamanan, misalnya setiap bangunan yang diidentifikasi dengan populasi umum dalam situasi palsu, harus secara mengejutkan berfokus pada keamanan. (4) Otonomi, misalnya setiap orang harus memiliki pilihan untuk mencapai, memasuki, dan memanfaatkan semua tempat atau struktur yang diidentifikasi dengan orang-orang pada umumnya di alam tanpa persyaratan untuk bantuan dari orang lain.

Penyesuaian yang harus dimungkinkan adalah penyesuaian pembelajaran membantu melalui persiapan inovasi pembelajaran yang disebut alteration. Sejalan dengan ini, penyesuaian yang disarankan untuk badan Sains saat ini untuk membuat perubahan pada tubuh Sains yang awalnya hanya sebagai bahan pembelajaran yang hanya diraba-raba di tengah-tengah auditif melalui ponsel. Selain itu, alteration middle dinamakan sebagai sound mid. Perubahan selesai dengan menggabungkan kode QR, pembelajaran suara, dan ponsel. Kombinasi tersebut adalah pendekatan untuk mengubah bantuan belajar dalam 
struktur visual (yang mereka gunakan melalui sentuhan) pada titik mereka disiapkan atau disesuaikan menjadi panduan suara.

Menurut penelitian yang dilakukan oleh Nisain Prihanaharin, (2019)materi pembelajaran media suara untuk pantun di kelas bahasa Indonesia IV di SDLB-A YPAB Surabaya diuji cobakan, dinyatakan dapat dicapai, dan kuat. Dari hasil validasi dan hasil uji coba perorangan, konsekuensi dari pendahuluan individu, cenderung disimpulkan bahwa media suara bahan sajak untuk siswa kelas IV Indonesia di SDLB-A YPAB Surabaya masuk akal untuk digunakan dalam pembelajaran. Dari efek setelah investigasi informasi ada perluasan dalam hasil pembelajaran pengganti. Ini dibuktikan dengan skor pre-test normal 61,67 sedangkan skor post-test normal 88,33 . Nilai normal menunjukkan bahwa penghargaan posttest yang dilakukan setelah penggunaan media suara lebih penting daripada pretest sebelum penggunaan media suara. Mengingat konsekuensi dari penilaian tanda tes mendapat hasil dengan derajat $\mathrm{Zh}$ 2,05 yang patut diperhatikan. Ketika kontras dan insentif dasar dalam uji tanda $(\mathrm{Zt})$ dengan tingkat kritis $0,5 \%$ dari 1,96 maka $\mathrm{Zh}>\mathrm{Zt}$. Pada saat itu cenderung disimpulkan bahwa ada dampak besar dari media suara pada kapasitas siswa untuk memahami materi untuk anakanak kelas empat di YLAB Surabaya Primary School. Secara keseluruhan, media suara menarik ketika diterapkan dalam pembelajaran kelas IV di YPAB Surabaya SDLB-A.

Pembelajaran kelas untuk anak tunanetra dalam memahami bentukbentuk wilayah khususnya pada mata pelajaran IPS membutuhkan media yang sesuai. Media yang digunakan dapat berupa peta timbul yang dapat dirasakan oleh anak tunanetra. Anak tunanetra yang dapat merasakan bentuk pada peta timbul akan menanmbah pengetahuannya akan tetapi mereka masih kurang memahami daerahdaerah yang ada di dalam peta. Peta timbul harus dikolaborasikan dengan audio agar anak tunetra dapat merasa dan mendegarkan informasi dari setiap daerah yang diraba. Pembelajara dengan merasakan dan mendengar membuat anak tunantra dapat lebih memahami pelajaran yang sedang 
diajarkan. Menurut penelitian dari Wicaksono, 2016 uji coba peta timbul yang dapat dirasakan dan audio yang dapat didengar oleh anak tunantra menunjukkan hasil yang cukup bagus dalam memahami wilayah yang ada dalam peta dan media yang digunakan ini layak untuk anak smp tunanetra.

Media audio chosen adalah sebuah media yang memiliki desain yang berguna memotivasi siswa dalam mempelajari isi dan informasi yang lebih detail serta mendalam. Media ini menonjolkan pada sisi dapat di putar atau diakses dimanapun dan kapanpun. Kemudahan yang diberikan media chosen dapat memberikan materi yang lebih banyak dan mudah dimengerti. Materi-materi yang diajarkan dapat diputar kembali dirumah untuk belajar secara mandiri. Media ini memiliki kelayakan dan memenuhi kriteria dari beberapa para ahli seperti isi dan materi yang komunikatif serta interaktif dan mudah dipahami. Menurut Hidayati and Pribadi (2014) media ini memberikan kesempatan kepada siswa untuk berfikir kritis dan menjawab dengan bantuan guru agar keaktifan siswa dapat meningkat secara signifikan dengan menggunakan media chosen.

Menurut Widiyaningsih (2017) anak tunanetra merupakan anak yang memiliki kekurangan dalam penglihatan hal ini menyebabkan guru memiliki tantangan yang berat untuk menjelaskan materi IPA yang membutuhkan banyak penalaran dan pemaham yang sulit diperoleh apabila tidak dapat melihat. Media pembelajaran yang tepat sangat diperlukan dalam menjelaskan salah satu materi IPA yaitu tata surya. Materi ini memiliki banyak pemahaman dan tingkat berfikir yang tinggi. Media pembelajaran berupa alat peraga dalam materi tata surya yang dibantu oleh audio dan label huruf braille ini akan mempermudah siswa tunanetra dalam memahami tata surya beserta letaknya. Alat ini mengabungkan bentuk dan suara agar anak tunanetra dapat meraba dan mendengarkan penjelasan yang diberi. Alat peraga ini mendapatkan penilaiannya yang sangat layak dalam segi audio dan alat peraga dari beberapa guru $(92,86 \%)$ dan mendapatkan respon $(91,07 \%)$ dari siswa. Alat peraga ini juga 
meningkatkan motavasi belajar setiap siswa tunanetra karena dorongan dari huruf, alat, dan suara yang dipadukan secara selaras.

\section{Penelitian yang dilakukan} menggunakan cara melakukan observasi pada mahasiswa yang tidak dapat melihat yang diberikan penanaman konsep dan pelatihan powerpoint dengan mengunakan media berbasis audio untuk penyampaian informasi yang diberikan. Mahasiswa yang menjadi subject dalam penelitian merupakan mahasiswa yang hadir di kelas teknologi dan media PAK dengan memiliki kekurangan dalam penglihatan serta tidak dapat mengakses media pratikum dengan visual serta hanya membutuhkan media audio. Media audio ini dipasang pada setiap laptop mahasiswa dengan terinstal aplikasi JAWS yang merupakan aplikasi pembaca audio dalam perangkat headset. Perangkat ini bergunakan untuk mengurangi kebisingan yang menggangu kenyamanan belajar serta memecah konsentrasi mahasiswa tunanetra. Media berfungsi untuk memudahkan siswa menghafal materi yang diberikan dosen melalui powerpoint dengan dapat didengar melalui aplikasi tersebut. Powerpoint akan menjadi suara yang dapat mudah dipahami oleh mahasiswa tunanetra. Media ini sangat mempermudah mahasiswa dalam mendengarakan pejelasan dosen di kelas yang terkadang masih kurang jelas. Media ini juga dapat digunakan pada semua jenjang pendidikan akan tetapi lebih efektif dipakai pada siswa smp dan sma yang telah mendapatakan pengetahuan yang lebih banyak melalui media powerpoint.

Media yang digunakan merupakan media audio dengan bahan ajar audio pada materi gerak . Materi ini menggunakan alat peraga besaran gerak dan ticker timmer sebagai visualisasi gambar untuk membantu audio. Media ini dapat digunakan optimal oleh penderita buta total dan kurang baik digunakan pada penderita buta yang masih dapat melihat cahaya/low vision. Media audio berbasis inkuiri sangat layak apabila digukan anak buta total serta dipadukan degan materi gerak berbantuan alat peraga. Hasil dari penelitian Munif (2016) presentasi kelayakan media 
audio untuk materi gerak berbantuan alat peraga sebesar (86,54\%), persentase kelayakan program audio sebesar $(87,50 \%)$, serta kelayakan alat peraga sebesar $(87,50 \%)$, presentase ini menunjukan bahwa materi dan media yang digunakan sangatlah selaras. Bahan ajar audio berbasis inkuiri pada materi gerak berbantuan alat peraga ini efektif dalam pengguasaan materi dengan melihat dan melakukan praktik dengan cara diraba. Media ini menunjukkan penguasaan materi dengan katagori sedang sebesar $(0,6)$.

Pembelajaran problem solving dalam penelitian silayusa, Dantes And Suarni (2015) pembelajaran problem solving membuat rata-rata motivasi belajar siswa meningkat menjadi 89,364 yang berada pada katageri tinggi. Pembelajaran ini menigkatkan motivasi siswa Denpasar dalam pembelajaran IPS yang diberikan. Metode problem solving menggunakan prinsip penggunaan metode pembelajaranyang melatih siswa untuk memecahkan masalah dan menghadapi berbagai resiko. Metode ini memberikan sebuah masalah yang harus dipecahkan peserta didik baik memecahkannya secara mandiri maupun kelompok-kelompok. Penelitian ini menenkankan masalah yang diberikan pada anak tunanetra dengan menggunakan media audio. Media audio ini berguna untuk membantu siswa dalam memecahkan masalah yang diberikan pada pembelajaran problem solving dengan mata pelajaran IPS.

Media yang diekembangkan adalah media audiobook yang dilengkapi alat peraga pada materi gelombang dan getar yang akan disampaikan. Media ini mengunakan alat peraga untuk memperkuat konsep yang diberikan media audiobook. Menurut penelitian Camalia (2016) media ini layak dan dan efektif digunakan dengan persentase kelayakan materi sebesar $(87,00 \%)$, persentase kelayakan media baik audio maupun alat peraga $(87,71 \%)$. Hasil dari media ini menunjukkan tingkat motavasi yang sedang dengan presentase sebesar 0,68. Alat peraga dan media ini memiliki keselarasan serta memudahkan anak tunanetra untuk mempelajari materi getar. 
Menurut (Fansury et al., 2019) menjabarkan bahwa Buku audio adalah materi pendidikan bahwa pelajar tunanetra dapat menggunakan dalam setiap situasidan setiap kali tanpa terikat pada apa puntempat atau tanpa bantuan orang lain. Audio buku yang bisa dibuat untuk pelajar tunanetra dapat membuatlingkungan untuk menyediakan, memperkaya, menginformasikan, membimbing dan mengajar mata pelajaran sepenuhnya dengan menciptakan sebuahlingkungan untuk belajar dan juga berkembangketerampilan belajar mandiri untuk menyelesaikan masalahdan menjawab pertanyaan serta berdiskusitopik terkait kursus yang berbeda. Audiobuku hanyalah sebuah buku yang diproduksi dalam formatitu terdengar. Buku audio dimulai diBahasa Spanyol dan segera berkembang menjadimedia multilinguistik. Banyak individu danperusahaan menggunakannya karena berbagai alasan.

Pada penelitian Moreno et al., (2016) mengembangkan aplikasi MALL yang bertujuan untuk membantu pembelajar bahasa inggris untuk mengajarkan keterampilan lisan mereka, terutama berbicara. Telah dikembangkanberangkat dari ide bahwa penggunaan Audio, yang menawarkan informasi yang sama yaitudiakses secara visual secara lisan, dapat menciptakan multimodal yang efektif dan memotivasi lingkungan belajar. VISP v1, sebagai versi uji coba, diuji pada pembelajaran jarak jauh siswa bahasa Inggris. Hasilnya menunjukkan potensi penerapan yang positif dan menjanjikan Audio ke aplikasi seluler yang bertujuan mempromosikan keterampilan lisan di FL, meskipun masih ada ruang untuk perbaikan. dalam penelitian ini masih belum sepenuhnya berhasil karena setiap individu mempunyaigaya belajar masing-masing.

Menurut (Hilmanaufar et al., 2019) fungsi media audio adalah untuk melatih segala kegiatan pengembangan keterampilan terutama yang berhubungan aspek keterampilan pendengaran. Selain itu pemahaman anak penderita tunanetra suatu materi jauh lebih baik menggunakan media audio berupa rekaman, karena kata-kata yang didengar jauh lebih jelas sehingga 
lebih mudah untuk dimengerti dan diingat. Karakteristik tunanetra yang menekannkan pada kekuatan mengingat objek, maka gigi harus dijaga dengan memprakteka menggosok gigi yag benar melalui rekaman.

\section{Kriteria Medio Audio}

Media audio sudah dirancang untuk anak tunanetra, akan tetapi media audio tersebut harus memenuhi beberapa kriteria. Kriteria media audio seperti media audio $\mathrm{Si}$ juara harus memiliki unsur yang terkait. Unsur ini adalah unsur Bahasa, Bahasa yang digunakan harus Bahasa yang mudah dipahami, tidak terlalu Panjang dan inovatif. Penelitian dari Rusmin Afandi Madjid mengungkapakan bahwa $\mathrm{Si}$ pintar dapat membantu anak tunanetra dalam melakukan pembelajaran. Si pintar ini sudah dirancang menggunakan media audio yang sudah sesuai unsur- unsur yang harus dimiliki audio dan menekannkan pada strategi. Media $\mathrm{Si}$ pintar dapat terpengaruh faktor internal dalam pembelajaran akan tetapi dapat dikurangi dengan menggunakan banyak strategi di setiap audio.

\section{KESIMPULAN}

Kesimpulan yang dapat kita peroleh dari penerapan bahan ajar audio untuk anak tunanetra smp adalah terwujudnya pendidikan yang merata baik anak normal maupun anak berkebutuhan khusus. Anak yang yang berkebutuhan khusus seperti tunanetra dapat memahami pembelajaran dengan media audio yang disetting menggunakan suara yang jelas dan mudah di pahami. Kelebihan media audio ini adalah dapat mudah memahami materi karena terkonsentraasi pada suara menjadikan tergabungnya perasaan dan fikiran yang dapat menyebabkan bayangan dan ingatan yang membekas. Hal yang perlu diperhatikan dalam penerapan media audio adalah faktor interaksi yang harus dibangun pengajar dengan peserta didik agar tercipta suasana yang hidup. Jika interaksi tidak terbangun maka media audio akan gagal digunakan pada anak tunanetra smp.

Dalam penelitian ini masih terdapat kekurangan karena peneliti belum menemukan jenis media audio vidio yang efektif untuk seluruh siswa tunanetra tingkat SMP, serta juga 
belum efektif untuk semua mata pelajaran. Oleh karena itu untuk menyempurnakan penelitian ini dapat melakukan pengkajian ulang sebelum diterapakan pada lingkungan belajar.

\section{UCAPAN TERIMA KASIH}

Dengan selesainya artikel telaah ini, saya mengucapkan Terima Kasih kepada Tuhan Yang Maha Esa karena atas Karunia dan RahmatNya saya dapat menyelesaikan artikel ini. Tak lupa, saya sampaikan Terima Kasih kepada Bapak Ence Surahman, S.Pd, M.Pd dan Ibu Dra. Susilaningsih, M.Pd. selaku pembimbing mata kuliah Karya Tulis Ilmiah Teknologi Pendidikan yang telah membantu, mengajarkan serta membei masukan dan saran terhadap artikel telaah ini.

\section{DAFTAR PUSTAKA}

Badiah, L. I. (2016). Keefektifan Pembelajaran IPA Dengan Menggunakan Modul Audio Interaktif Mengenal Bagian Akar Dan Fungsinya Untuk Siswa Tunanetra Kelas IV DI SLB YPAB Surabaya. HELPER: Jurnal Bimbingan Dan Konseling, 32(2). Budiarso, A. S. (2016). Pengembangan
Bahan Ajar Berbasis Metode Hypnoteaching Untuk Memotivasi Siswa SMP Dalam Belajar IPA Pada Materi Energi Terbarukan. Jurnal Pena Sains, 3(2), 132-141.

Camalia, F. (2016). Pengembangan Audiobook Dilengkapi Alat Peraga Materi Getaran Dan Gelombang Untuk Tunanetra Kelas VIII SMP. Universitas Negeri Semarang.

Dariyati, I. G. A., Marhaeni, D. R. A. A. I. N. G. R., \& Widiartini, D. R. N. I. K. (2015). Pengaruh Pembelajaran Praktik Berbantuan Media Audio Terhadap Kemampuan Motorik Dan Motivasi Belajar Siswa Smp Di Slb A Negeri Denpasar. Jurnal Penelitian Dan Evaluasi Pendidikan Indonesia, 5(1).

Delani, R. (2017). Efektivitas Penggunaan Media Audio "Solusi Pintar Jelas Dan Mudah"(Splash) Terhadap Hasil Belajar Pada Siswa Tunanetra Di Mtslb Yaketunis Yogyakarta. E-Jurnal Skripsi Program Studi Teknologi Pendidikan, 6(2), 168-175. 
Fansury, A. H., Lutfin, N., \& Arsyad, S. N. (2019). Audio Books as Teaching Media to Blind Students in Learning EFL. KLASIKAL: JOURNAL OF EDUCATION, LANGUAGE TEACHING AND SCIENCE, 1(1), 1-9.

Fatihatul, R., \& Budiawanti, S. (2013).

Pembuatan Media Pembelajaran

Berupa Kit Percobaan Penentuan

Percepatan Gravitasi Dengan

Menggunakan Neraca Pegas

Braille Untuk Siswa Tunanetra

Kelas VIII. PROSIDING:

Seminar Nasional Fisika Dan Pendidikan Fisika, 4(3).

Haryoko, S. (2012). Efektivitas pemanfaatan media audio-visual sebagai alternatif optimalisasi model pembelajaran. Jurnal Edukasi Elektro, 5(1).

Hidayati, F., \& Pribadi, T. A. (2014).

Pengembangan Media Audio Characteristics Of Organism Song Education (Chosen) Pada Pembelajaran IPA Biologi Di SMPLB-A (Tunanetra). Journal of Biology Education, 3(2).

Hilmanaufar, D. M., Arti, D. W. K., \& Failasufa, H. (2019). Pengaruh
Metode Penyuluhan Audio Taktil Kesehatan Gigi Dan Mulut Terhadap Penurunan Indeks Plak Siswa Tunanetra di SLB Semarang. Prosiding Seminar Nasional Mahasiswa Unimus, 2. Indrastuti, F. (2015). Efektifitas Media Pembelajaran Audio Melalui Cerita Pendidikan Berkarakter Untuk Tunanetra Jenjang Smp. Jurnal Rehabilitasi Dan Remediasi, 24(1).

Khamdun, K. (2015). Media Pembelajaran IPA Berbasis Alam Untuk Siswa Tunanetra Dalam Pendidikan Karakter. Prosiding SNPS (Seminar Nasional Pendidikan Sains), 2, 524-532.

Laksono, P. T. (2016). Musik sebagai media komunikasi antara orang tua dengan anak berkebutuhan khusus di yayasan tunanetra Bina Tuntas Siwalankerto. UIN Sunan Ampel Surabaya.

Masruro, E. A., \& Winarti, W. (2012). Pengembangan Modul IPA Fisika SMP Materi Suhu Untuk Siswa Tunanetra. PROSIDING: Seminar Nasional Fisika Dan Pendidikan Fisika, 3(5). 
Moreno, A. I., Vermeulen, A., \& Jordano, M. (2016). 21Using audio description to improve FLL students' oral competence in MALL: methodological preliminaries. New Perspectives on Teaching and Working with Languages in the Digital Era, 245.

Mulyono, D. B. (n.d.). Model Bahan

Ajar Bahasa Dan Sastra Indonesia Yang Ideal Dan Inovatif. Edukasi Kultura: Jurnal Bahasa, Sastra Dan Budaya, 1(1).

Munif, A. (2016). Pengembangan Bahan Ajar Audio Berbasis Inkuiri Berbantuan Alat Peraga Pada Materi Gerak Untuk Anak Tunanetra Kelas Vii Smp/Mts Lb. Universitas Negeri Semarang.

Nisain Prihnaharin, F. (2019). Pengembangan Media Audio Dengan Bahan Pelengkap Braille Materi Pantun Anak Mata Pelajaran Bahasa Indonesia Kelas Iv Sdlb-A Ypab Surabaya. Jurnal Mahasiswa Teknologi Pendidikan, 9(2).

Priambodo, F. P. (2019). Meningkatkan kemampuan menulis tunanetra melalui penggunaan CBM
(Curriculum

Based

Measurement).

SKRIPSI

Mahasiswa UM.

Sari, A. C., Fadillah, A. M., Jonathan, J., \& Prabowo, M. R. D. (2019). Interactive Gamification Learning Media Application For Blind Children Using Android Smartphone in Indonesia. Procedia Computer Science, 157, 589-595.

Satrio, B. Y. D. (2016). Modul Kimia Berbasis EPUB Untuk Siswa Tunanetra: Materi Larutan Elektrolit Dan Non-Elektrolit. Inklusi, 3(1), 87-100.

Silayusa, N. P., DANTES, D. R. N., \& SUARNI, D. R. N. I. K. (2015). Pengaruh Metode Pembelajaran Problem Solving Berbantuan Media Audio Terhadap Motivasi Belajar dan Prestasi Belajar IPS Siswa SMALB di SLB A Negeri Denpasar. Jurnal Penelitian Dan Evaluasi Pendidikan Indonesia, $5(1)$.

Sulfemi, W. B. (2019). Penggunaan Metode Demontrasi Dan Media Audio Visual Dalam Meningkatkan Hasil Belajar 
Peserta Didik Mata Pelajaran Ips.

Tirta, T., Susanto, S., \& Kristiani, A. I. (2013). Pengembangan Alat Peraga Matematika Berbasis Audio Pada Pokok Bahasan Keliling Dan Luas Segitiga Untuk Siswa Tunanetra Smplb Tpa Jember. KadikmA, 4(1).

Ulya, E. (2014). Efektivitas Media Booklet Braille Dalam Meningkatkan Pengetahuan Gizi Pada Anak Tunanetra. Unnes Journal of Public Health, 3(4).

Undang-Undang, R. I. (2003). No. 20

Tahun 2003. Tentang Sistem Pendidikan Nasional, 9.

Wicaksono, R. B. (2016).

Pengembangan Perangkat Media Audio Peta Timbul (Peradiotim) Materi Bentuk Muka Bumi Bagi Siswa Tunanetra Di Mtslb-A Yaketunis Yogyakarta. E-Jurnal Skripsi Program Studi Teknologi Pendidikan, 5(4).

Widiyaningsih, T. (2017).

Pengembangan Alat Peraga Tata Surya Berbantuan Audio Untuk Meningkatkan Motivasi Dan Hasil Belajar Siswa Tunanetra Smp Lb Kelas VIII. Universitas Negeri
Semarang.

Widyastuti, R. (2016). Pola Interaksi Guru dan Siswa Tunanetra. AlJabar: Jurnal Pendidikan Matematika, 7(2), 257-266.

Wijaya, E. M. (2016). Pengembangan bahan ajar SKI berbasis multimedia interaktif untuk meningkatkan hasil belajar siswa kelas VII di MTs An-Nur Bululawang. Universitas Islam Negeri Maulana Malik Ibrahim 